\title{
Patterns of dietary change: the Scandinavian experience
}

\section{By Dag S. Thelle Institute of Community Medicine, University of Troms $\phi$, Boks 417, 9001 Troms $\emptyset$, Norway}

Sunday afternoon 10 August 1628 , the naval vessel Wasa embarked on its first trip. The ship had been constructed in Stockholm according to the King's wishes, and the recommendations of one of the most renowned ship builders at that time. It was heavily decorated, with sculptures both in the bow and the stern. It was armed with sixty-four bronze cannon, at that time a heavy armament, and the ship was meant to impress, frighten and to fight the enemy. It was a beautiful afternoon when the ship was pulled off the shore. Four sails were set and were quickly filled. A sudden increase in the wind made the ship tilt. The water flooded the cannon gates and she sank in only a few minutes, with standing sails, flag and all men aboard, actually also a number of women and children. It was a catastrophe; a thoroughly-designed naval vessel, among the largest ever built, went down on its first trip. Today the vessel is a remarkable source of knowledge about seamen's life in the 17th century.

On 17 November 1975 the Norwegian government put forward a Parliamentary Bill on Norwegian nutrition policy and food supply (Royal Norwegian Ministry of Agriculture 1976). The following four goals deserve to be mentioned.

1. To encourage a health-promoting diet, mainly by reducing overall fat consumption, especially saturated fat, and replace it with polyunsaturated fat, whole grains and vegetables.

2. To promote domestic food production and reduce food imports, thereby increasing self-sufficiency from 39 to $52 \%$ of total energy by 1990 .

3. To promote agricultural development in Norway's less-advanced, outlying regions with due regard for preserving the environmental resource base.

4. To contribute to world food security, promoting food production and consumption in poor countries.

Four very ambitious goals, with some clearly inherent conflicts. Today, more than 10 years later, some of us are claiming that these conflicting aims may be similar to that of building top-heavy sculptures and impressive cannon on a ship, but not ensuring the sailing capability. A small breeze from agriculture, the food industry or other sectional interests would be sufficient to tilt and eventually sink this policy and leave following generations to study its basis, its shape and its decorations.

Is this an unfair description? Before trying to show what took place in Norway, two other Parliamentary Bills deserve to be mentioned, both based on the same sort of ideas as the first one, namely, that it is a public responsibility to monitor the environment, thereby also nutrition, and if necessary take the steps required to promote the health of the population. One Bill is a report on the follow-up of the Norwegian nutrition policy (Royal Ministry of Health and Social Affairs, 1982). This report re-emphasises the relation between nutrition and health, paying particular attention to the results of the intervention trial on individuals at high-risk of cardiovascular disease in Oslo (Hjermann et al. 1981). It also points to the short period of time which had elapsed between the introduction of the first Bill (Royal Norwegian Ministry of Agriculture, 1976) and the 


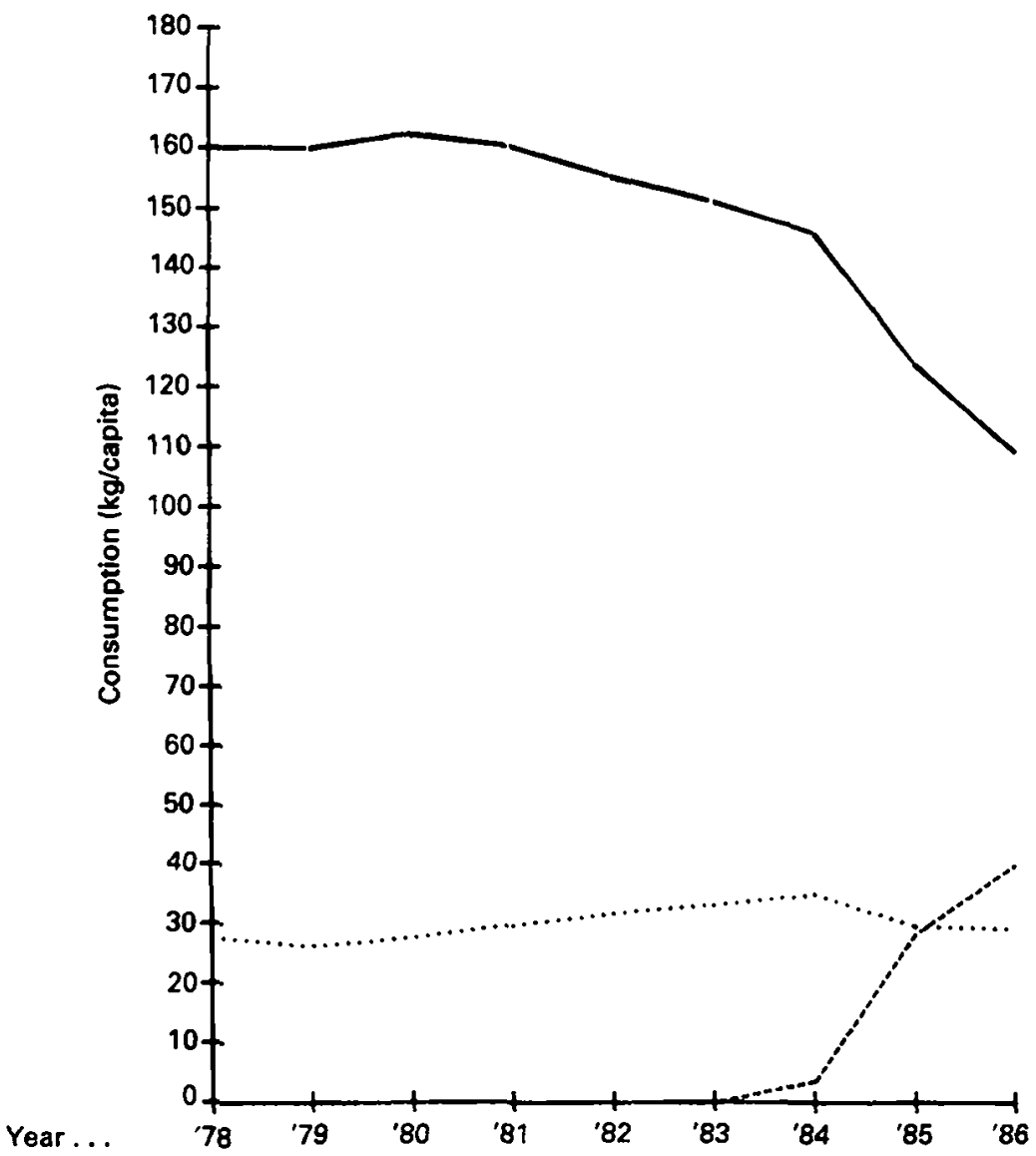

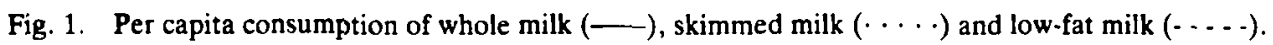

writing of the follow-up Bill, admitting that small changes had occurred. However, the follow-up Bill also pointed to another aspect which is too often forgotten; that instruments are needed to monitor nutrition policy. One of the instruments would be a continuous surveillance of the population's health to identify negative trends. We are still lacking statistics for the incidence of cardiovascular diseases. Routine registration of any diseases connected with nutrition is non-existent. There is no formalized collaboration between those responsible for the cancer registry, death registry and other disease registers in Norway, and those responsible for implementing nutrition policy.

The 1982 Bill states that information work on nutrition should be co-ordinated at central government, county and local government levels. Information-gathering efforts directed towards the groups where information is greatest will be given high priority. Co-ordination should take place via the county health officer, who should therefore improve his/her competence in the dietary and nutrition field. This sounds like a nice set-up, and I agree that this is the way it should be. The problem is that it has not been implemented as such except in one county, and then only as an experiment.

The third official political paper on this issue is a Parliamentary Bill on health promotion and preventive medicine in the community or at a municipal level (Royal Ministry of Health and Social Affairs, 1987). In this Bill nutrition has been included as 
one of the environmental factors influencing health. Clear quantitative goals for the year 2000 have been drawn up, and again emphasis is put on nutrition.

These three political documents form the basis for the Norwegian nutrition policy. Obviously there exists a political will, aiming at promoting health by interfering with the nutrition situation. This political will is also demonstrated in the other Nordic countries. The Swedish Parliament laid down guidelines for diet and health in 1985 and is in the process of developing a programme of action. In Finland the Ministry of Social Affairs and Health established a committee in 1979 which is to produce a uniform programme by 1990. In Denmark a food act was endorsed by the Parliament, but 'nutrition policy in Denmark is governed by the Ministries of Environment, Agriculture, Fisheries, and Industry . . . ad hoc legislations have defeated the food policy act'.

I shall now describe some of the changes which have occurred in the Norwegian population. Thereafter, I shall discuss the possible relation between the nutrition policy and these changes.

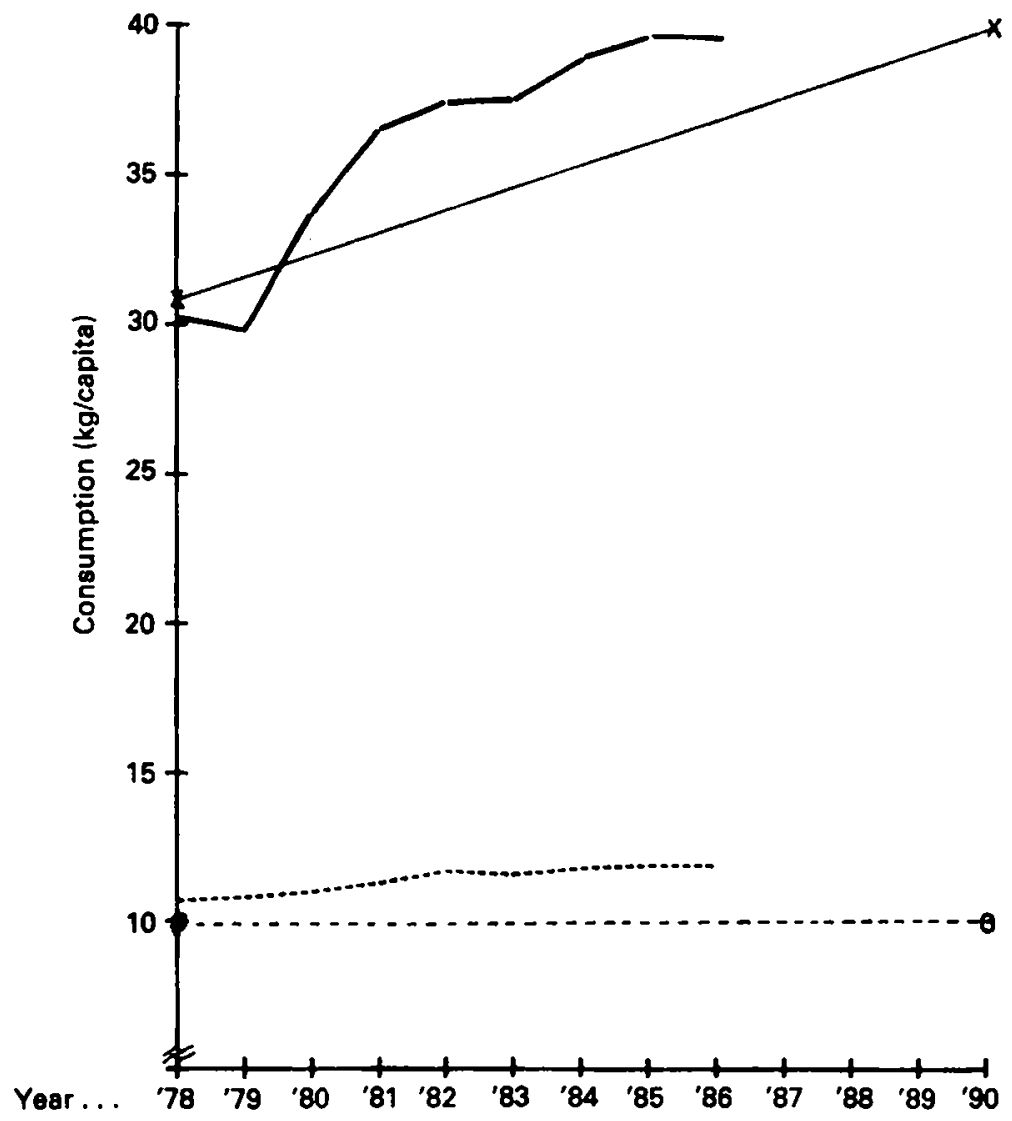

Fig. 2. Per capita consumption of fish (-) and eggs (- . - -) and respective forecasts of consumption $(x-x ; 0-. .-0)$. 


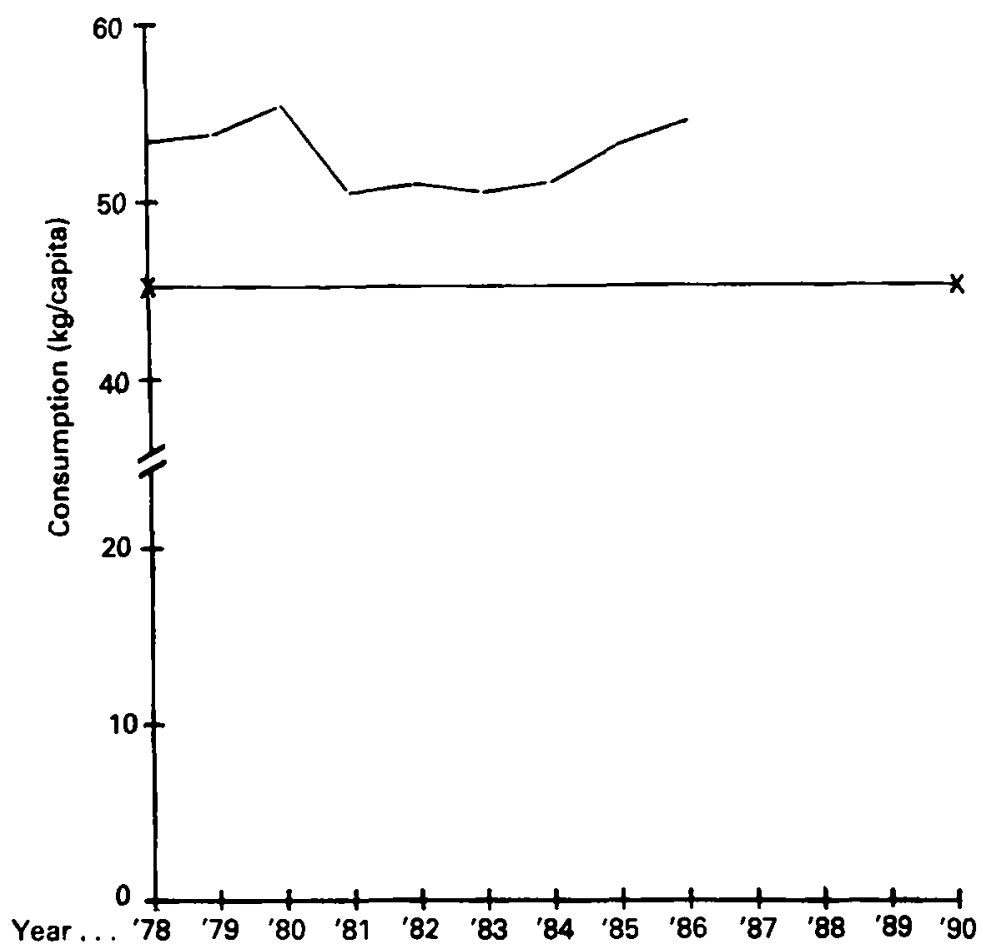

Fig. 3. Per capita consumption of meat $(-)$, and forecast of meat consumption $(x-x)$.

\section{Food supply and consumption}

The food supply in Norway provides access to a varied and healthy nutrition pattern. The food policy set some goals with regard to food items. The following figures are based on household surveys run by the Central Statistics Bureau of Norway.

Milk. From the 1970s to 1984 there was a steady increase in the use of skimmed milk (Fig. 1). At the same time consumption of whole-fat milk decreased considerably. During the last few years the total consumption of milk, which has always been high in Norway, has decreased. In 1984 low-fat milk with $1.5 \%$ fat was introduced and has mainly taken the market from whole-fat milk. Of the milk consumed, $60 \%$ is drunk.

Fish. One of the major constituents of the Norwegian diet is fish (Fig. 2). There seems to be an increase in consumption, but here figures are very difficult to obtain. However, the consumption of fish is encouraged and with prices competitive with meat prices, it is more a question of marketing than anything else.

Meat. There was a considerable increase in the consumption of meat from 1970 to 1980 , thereafter a slow decrease, and the situation now seems stable. There is, however, a particular feature with Norwegian meat consumption, that $60 \%$ of the meat is consumed as ground pre-fabricated products. Most of these sausages and meat balls are produced by the butchers, and the fat content of these products may vary considerably and is obviously higher than if raw meat were the basis of consumption. 


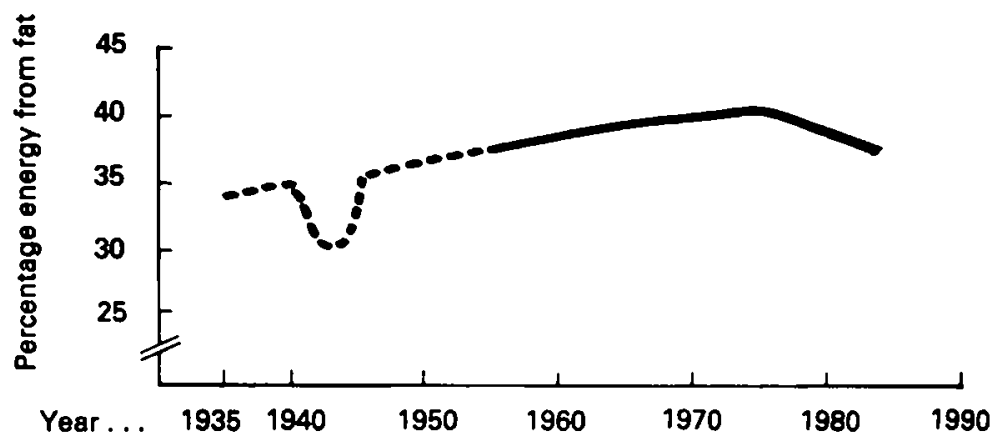

Fig. 4. Fat consumption ( $\%$ of energy intake).

The aim of the Parliamentary Bill on nutrition was that the percentage of energy from fat should not exceed 35, and looking at the development from the 1930s to the present day reveals a steady increase from a level below $35 \%$ to almost $40 \%$ followed by a gradual decrease to approximately $36 \%$ (Fig. 4). The total daily intake of fat per person is approximately $106 \mathrm{~g}$, of which table fat constitutes $38 \%$. In this context margarine is the major source of fat. It is, therefore, of major importance that the trend towards more soft margarine is encouraged. Butter constitutes only a minor part of the total table fat intake. Again, among the dairy products milk is a major fat source, with meat of less relative importance.

Until recently the price of milk to the farmer has been determined by the fat content, thereby stimulating high-fat milk production. With the increasing over-production of milk, the farmers have gradually realized tht the market has changed and there is now a swing towards paying for the higher protein content of the milk. The correlation between protein and fat contents of milk is high, and as this change has not occurred everywhere, the impact of the measure is difficult to assess.

The figures quoted so far are average figures, based on household surveys. They do not relate to the distribution of the nutritional habits in the Norwegian population. From our population surveys we have information indicating that there are considerable socioeconomic gradients, with those from the highest social classes being the leanest, and having the healthiest eating habits (Table 1; Jacobsen \& Thelle, 1988). It seems as if the nutritional habits have changed in a positive direction among those in the highest social classes or in those who have had the longest period of education. Such differences imply at least a $20 \%$ difference in coronary heart disease risk.

\section{Fat, a waste product}

In a recent discussion with the dairy industry, agricultural scientists and authorities, it was suggested that fat from dairy products should be looked on as an unwanted waste product. Accordingly the value should be set at zero, thereby not encouraging the production of fat.

Total table fat consumption has decreased due to a decrease in the use of hard margarine which was the predominant form of table fat in Norwegian households (Fig. 5). Of total margarine consumption, $43 \%$ is now soft margarine. In 1985 a new margarine product containing a relatively large proportion of butter was introduced, thus decreasing the polyunsaturated:saturated fat ratio in the diet, which had until then shown a very positive trend. 
Table 1. Age-adjusted associations between duration of education and mean body mass index (BMI), daily smokers, physical activity in leisure time* and some food habits of men aged 25-54 years, and women aged 25-49 years (From Tromsø Heart Study 1979-80 (Jacobsen \& Thelle, 1988))

\begin{tabular}{|c|c|c|c|c|c|c|c|c|c|c|c|c|c|c|}
\hline \multirow{2}{*}{$\begin{array}{l}\text { Duration of } \\
\text { education } \\
\text { (years) }\end{array}$} & \multicolumn{2}{|c|}{ BMI } & \multicolumn{2}{|c|}{$\begin{array}{l}\text { Percentage } \\
\text { smokers }\end{array}$} & \multicolumn{2}{|c|}{$\begin{array}{l}\text { Percentage } \\
\text { exercising }\end{array}$} & \multicolumn{2}{|c|}{$\begin{array}{l}\text { Percentage } \\
\text { drinking } \\
>4 \text { cups of } \\
\text { coffee/d }\end{array}$} & \multicolumn{2}{|c|}{$\begin{array}{l}\text { Percentage } \\
\text { using } \\
\text { soft } \\
\text { margarine }\end{array}$} & \multicolumn{2}{|c|}{$\begin{array}{l}\text { Percentage } \\
\text { drinking } \\
\text { low-fat milk }\end{array}$} & \multicolumn{2}{|c|}{$\begin{array}{l}\text { Percentage } \\
\text { eating } \\
\text { fruits or } \\
\text { vegetables } \\
\text { daily }\end{array}$} \\
\hline & $\delta$ & q & $\sigma^{*}$ & 9 & 8 & $q$ & $\delta$ & $q$ & 6 & $q$ & $\delta$ & q & $\delta$ & q \\
\hline$<8$ & $24 \cdot 7$ & 23.5 & 61 & 55 & 28 & 11 & 73 & 65 & 66 & 67 & 17 & 26 & 27 & 43 \\
\hline $8-10$ & $24 \cdot 7$ & 22.9 & 57 & 51 & 31 & 12 & 6 & 57 & 7 & 75 & 2 & 35 & 37 & 62 \\
\hline $11-12$ & $24 \cdot 5$ & $22 \cdot 4$ & 47 & 42 & 34 & 13 & 60 & 49 & 76 & 78 & 30 & 41 & 49 & 74 \\
\hline $13-16$ & $24 \cdot 3$ & $22 \cdot 3$ & 39 & 27 & 38 & 15 & 56 & 37 & 75 & 78 & 36 & 51 & 55 & 83 \\
\hline$>16$ & $23 \cdot 8$ & $22 \cdot 1$ & 27 & 21 & 39 & 18 & 46 & 32 & 75 & 69 & 48 & 54 & 68 & 88 \\
\hline
\end{tabular}

*Exercises 4 or more h/week

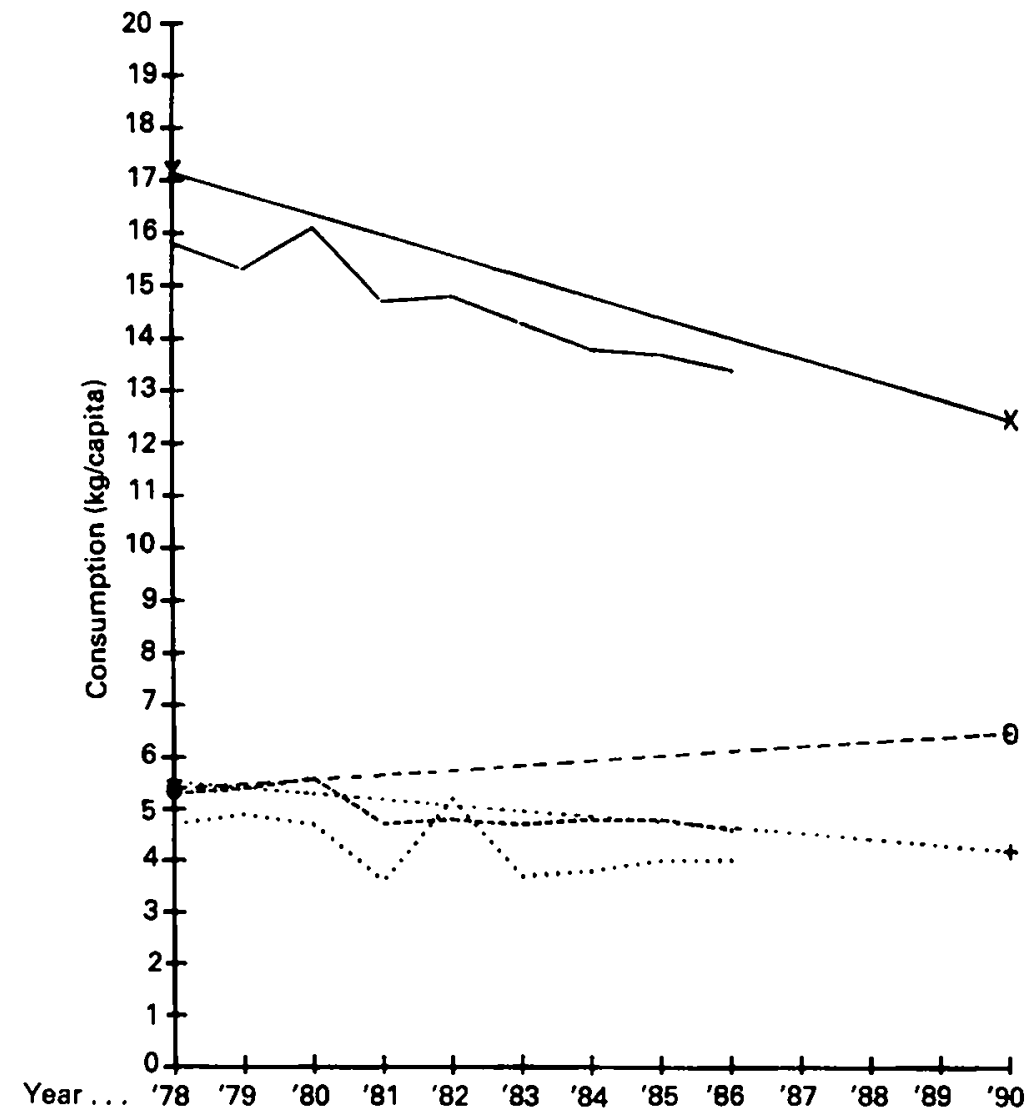

Fig. 5. Per capita consumption of margarine (-), butter $(-\cdots)$ and other fats $(\cdots \cdots)$ and respective forecasts of consumption $(x-x ; 0, \cdots,+\cdots+)$. 
What have these changes to do with nutrition policy? I started by pointing out that there are some inborn contradictions in the Norwegian nutrition policy. As it was realized that there were different sectors with differing views and interests, it was decided that research was needed on how to develop means to implement the policy. The research has been co-ordinated and funded by a cross-sectional, cross-departmental Research Council comprising agriculture, social and medical sciences, consumer associations, and the fishing industry. The aim of this council is to promote research into the following areas: (1) how to change people's eating habits (i.e. health education, different methods, different target groups, etc.), (2) to what extent eating habits are dependent on pricing policy, (3) dietary patterns in particular groups, e.g. the elderly and small children, and (4) on the more political side, what are the conflicts between agriculture and the nutrition policy?

If the political means are considered, i.e. the available instruments for the politicians really to influence dietary patterns, then these will be found in the large subsidies to the farmers and to the consumers. The way in which these subsidies are used will be signals both to the producers and to the consumers as to which food items the authorities encourage. At this stage the encouragement goes into an increased consumption of milk, butter and other high-fat-containing products. The only way to change these subsidies is to down-grade the value of fat, i.e. to put its value at zero; fat would become an unwanted product which could then be used as a cheap raw material for technical purposes, e.g. in the cosmetic industry. Such ideas are also slowly gaining ground in the agricultural sphere, and the aforementioned research council is encouraging development in this direction.

Another obstacle which must be overcome is the import-export regulations on vegetables which are there to protect Norwegian farmers. However, some of the products are produced by so few people and are, in economic terms, of minor importance. Still, the regulations may increase the prices considerably, making for instance tomatoes and green vegetables, especially during the winter, much more expensive than necessary. This discourages the use of vegetables in population groups which by tradition have consumed relatively few vegetables.

The third area which is being encouraged is research into low-fat-milk-producing cows and lean-slaughter animals.

The main question with regard to the observed changes in the dietary pattern in Norway is whether these would have occurred if we had not had a nutrition policy. Is the Parliamentary Bill anything more than the ship which sank outside the harbour of Stockholm? I think it is. It is really a basis for a policy which must be contradictory. But it is my view that without a nutrition policy, without a conscious idea of where to go, a lot of the changes presented here would never have taken place. Whether the observed

Table 2. Annual percentage changes* in mortality rates in men and women aged 35-64 years in four Nordic countries (1969-1981)

\begin{tabular}{|c|c|c|c|c|c|c|c|c|}
\hline & \multicolumn{2}{|c|}{ Denmark } & \multicolumn{2}{|c|}{ Finland } & \multicolumn{2}{|c|}{ Norway } & \multicolumn{2}{|c|}{ Sweden } \\
\hline & Men & Women & Men & Women & Men & Women & Men & Women \\
\hline All causes & - & - & $-2 \cdot 3$ & $-3 \cdot 2$ & -0.6 & $-1 \cdot 2$ & - & $-1 \cdot 3$ \\
\hline All cancer & - & - & $-2 \cdot 0$ & -0.6 & - & - & - & -0.4 \\
\hline All CVD & - & $-1 \cdot 2$ & $-2 \cdot 4$ & $-5 \cdot 2$ & $-1 \cdot 0$ & $-2 \cdot 8$ & +0.4 & $-2 \cdot 9$ \\
\hline IHD & +0.8 & - & -1.7 & $-2 \cdot 8$ & -0.8 & $-1 \cdot 2$ & $+1 \cdot 3$ & $-1 \cdot 0$ \\
\hline
\end{tabular}

CVD, cardiovascular disease; IHD, ischaemic heart disease.

*All changes were significant: $P<0.05$ 
changes in coronary mortality rates (Table 2 ) would have occurred without this policy is a more difficult question. The striking changes which were observed in Finland suggest an interplay between the general trend in the enlightened public, the health authorities, and the policy makers. Even if we have not fulfilled the obligations set up in the first Bill, we have still managed to keep the level of consciousness high and thereby encouraged continuous research into this extremely complicated field.

Where are we going in the future? Oddly enough, industry seems to be more on our side than agriculture. Industry is more susceptible to changes in the market and has to adapt more quickly than the heavily-regulated, planned agriculture. This suggests deregulation of Norwegian agriculture in order to promote increased import of vegetables during the time of the year when this is needed, and increased production of low-fat products by defining dairy fat as a waste product of no value.

\section{REFERENCES}

Hjermann, I., Byre, K., Holme, I. \& Leren, P. (1981). Lancet ï, 1303-1310.

Jacobsen, B. K. \& Thelle, D. S. (1988). American Journal of Epidemiology (In the Press).

Royal Ministry of Health and Social Affairs (1982). Report no. 11 to the Storting (1981-1982) on the Follow-up of Norwegian Nutrition Policy. Oslo: Royal Ministry of Health and Social Affairs.

Royal Ministry of Health and Social Affairs (1987). Environmental Medicine in the Municipalities, Ot. prp. no. 40. Oslo: Royal Ministry of Health and Social Affairs. (Norwegian only).

Royal Norwegian Ministry of Agriculture (1976). Report no. 32 to the Storting (1975-1976) on Norwegian Nutrition and Food Policy. Oslo: Royal Norwegian Ministry of Agriculture. 